Vegetalika. 2017. 6(2): 14-24

\title{
Pendugaan Parameter Genetik Komponen Hasil untuk Seleksi Tidak Langsung Tanaman Padi (Oryza sativa L.) Berdaya Hasil Tinggi
}

\section{Estimation of Yield Component's Genetic Parameters for High Yielding Rice (Oryza sativa L.) Indirect Selection}

\author{
M. Mujadid Faiqon ${ }^{1)}$, Supriyanta ${ }^{2^{*}}$, Rani Agustina Wulandari ${ }^{2)}$ \\ 1) Program Studi Pemuliaan Tanaman, Fakultas Pertanian, Universitas Gadjah Mada \\ 2) Departemen Budidaya Pertanian, Fakultas Pertanian, Universitas Gadjah Mada \\ *) Penulis untuk korespodensi E-mail: anta_supri@yahoo.com
}

\begin{abstract}
Direct selection on yield is often difficult to be done due to yield's complex nature and it's highly affected by environment. Indirect selection by selecting yield component correlated with yield could be a solution for this problem. Estimation of genetic parameters was done to identify yield components that could improve yield per hectare through indirect selection. Nine genotypes of rice are assumed to be following random distribution was planted on two different sites, Klaten and Sleman, each following RCBD environmental design. Components of variance and covariance estimated by ANOVA and ANCOVA were used to estimate heritability, genetic correlation, coheritability, and expected $C R A / R A$ ratio. Further analysis of genetic correlation using path analysis was done to gain more information about the relationship between yield and yield components. Plant height, flag leaf length, days to heading, days to maturity, 100 grains weight, number of panicle per hill, panicle length, and panicle density have high heritability (more than 0,7), higher than yield per hectare on each site $(0,55$ on Klaten and 0,42 on Sleman). Number of panicle per hill has positive and high genetic correlation with yield per hectare while flag leaf length and days to heading have positive and high direct effects on yield per hectare on Klaten site. Weight of 100 grains and panicle length have positive and high genetic correlation with yield per hectare while plant height and number of seeds per panicle have positive and high direct effects on yield per hectare on Sleman site. Unfortunately, no yield component has expected CRA/RA ratio more than 1, proved that no yield components could be used to improve yield per hectare genetically through indirect selection. Direct selection on yield proved to be more effective than indirect selection based on yield component.
\end{abstract}

Keywords : indirect selection, yield components, genetic correlation, path analysis

\section{INTISARI}

Seleksi langsung terhadap daya hasil seringkali sulit dilakukan karena sifat alami hasil yang kompleks dan besarnya pengaruh lingkungan terhadap hasil. Seleksi tidak langsung mendasarkan pada komponen hasil yang berkorelasi terhadap hasil dapat dilakukan sebagai solusi untuk masalah tersebut. Pendugaan parameter genetik dilakukan untuk memperoleh informasi mengenai komponen hasil yang dapat digunakan untuk meningkatkan hasil per hektar. Sembilan genotipe padi diasumsikan berdistribusi random ditanam mengikuti rancangan RCBD di dua lokasi, Klaten dan Sleman. Komponen varian dan kovarian yang diduga melalui ANOVA dan ANCOVA 
digunakan untuk menduga heritabilitas, korelasi genetik, koheritabilitas, dan rasio nilai harapan CRA/RA. Analisis lebih lanjut untuk korelasi genetik dilakukan dengan analisis lintas untuk memperoleh informasi tambahan mengenai hubungan antara hasil dengan komponen hasil. Tinggi tanaman, panjang daun bendera, umur berbunga, umur panen, bobot 100 butir biji, jumlah malai per rumpun, panjang malai, dan kerapatan malai diketahui memiliki heritabilitas tinggi (lebih dari 0,7 ) dan lebih tinggi dibandingkan heritabilitas hasil per hektar (0,55 di Klaten dan 0,42 di Sleman). Jumlah malai per rumpun memiliki korelasi genetik positif dan tinggi dengan hasil per hektar sementara panjang daun bendera dan umur berbunga memiliki pengaruh langsung positif dan tinggi terhadap hasil per hektar di lokasi Klaten. Bobot 100 butir biji dan panjang malai memiliki korelasi genetik yang positif dan tinggi terhadap hasil per hektar sementara tinggi tanaman dan jumlah biji per malai memiliki pengaruh langsung yang tinggi dan positif. Akan tetapi, tidak terdapat komponen hasil yang memiliki rasio nilai harapan CRA/RA lebih tinggi dari 1 yang menunjukkan bahwa tidak ada komponen hasil yang dapat meningkatkan kemajuan genetik hasil per hektar melalui seleksi tidak langsung. Seleksi langsung terhadap daya hasil lebih efektif dibandingkan dengan seleksi tidak langsung melalui komponen hasil tertentu.

Kata kunci : seleksi tidak langsung, komponen hasil, korelasi genetik, analisis lintas

\section{PENDAHULUAN}

Padi merupakan tanaman pangan paling penting di Indonesia. Konsumsi per kapita yang tinggi mencapai 97,4 kg/kapita/tahun (Anonim, 2014) akan menyebabkan kebutuhan padi meningkat akibat adanya kenaikan jumlah penduduk. Sementara itu produktivitas padi nasional berkisar pada angka 5,339 ton/ha (Anonim, 2016), jauh lebih rendah dibanding potensi daya hasil padi tropis yang mencapai 10 ton/ha (Peng et al., 1999). Peningkatan kemampuan daya hasil kultivar padi yang digunaka harus terus dilakukan melalui pemuliaan tanaman. Meningkatnya produktivitas padi nasional merupakan tujuan dari pemuliaan tanaman padi, namun pemuliaan tanaman padi untuk peningkatan daya hasil kerap sulit dilakukan karena sifat hasil yang kompleks dan besarnya pengaruh lingkungan terhadap hasil (Roy, 2000). Keragamannya pun banyak disebabkan oleh keragaman lingkungan dan tidak terwariskan (Poehlman, 1987). Salah satu strategi untuk menangani masalah tersebut adalah dengan menggunakan seleksi tidak langsung mendasarkan pada komponen hasil (Ali et al., 2000). Suatu komponen hasil dapat digunakan untuk meningkatkan hasil bila memiliki heritabilitas yang tinggi dan berkorelasi secara genetik terhadap hasil. Pendugaan parameter menjadi penting dilakukan untuk menjawab syarat tersebut (Falconer and Mackay, 1996). Pendugaan parameter genetik pada komponen hasil dilakukan untuk menentukan komponen hasil yang dapat digunakan untuk mengidentifikasi sifat yang dapat digunakan sebagai sifat yang dipilih dalam seleksi tidak langsung peningkatan daya hasil padi. 


\section{BAHAN DAN METODE}

Penelitian dilakukan pada bulan Juli 2015-Januari 2016 di Kebun PIAT, Berbah, Sleman dan di lahan petani di dusun Trasan, Juwiring, Klaten. Sembilan genotipe yang digunakan terdiri dari 'UGM 8', 'UGM 11', 'UGM 28', 'UGM 30', 'UGM 1271', 'IR64', 'Memberamo', 'Pak Tiwi-l', dan 'Memberamo'. Alat dan bahan lain yang digunakan adalah pupuk, pestisida, serta sarana produksi pertanian lain untuk pertanaman padi. Rancangan percobaan pada masing-masing lokasi menggunakan rancangan acak lengkap kelompok lengkap (RAKL) dengan tiga blok sebagai ulangan. Genotipe sebagai perlakuan dianggap mewakili populasi padi pada umumnya. Bila varian kedua lokasi homogen, maka rancangan akan disatukan menjadi rancangan split plot berbasis RAKL dengan faktor utama berupa lokasi dan faktor kedua berupa genotipe. Uji lanjut dilakukan menggunakan uji LSD pada tingkat kepercayaan $95 \%$. Varian dan kovarian genetik diduga menggunakan ANOVA dan ANCOVA dengan rancangan seperti yang sudah disebutkan. Heritabilitas, korelasi genetik, analisis lintas, dan rasio nilai harapan CRA/RA diduga berdasarkan komponen varian dan kovarian yang sudah diduga sebelumnya. Nilai yang tidak dapat didefinisikan tidak ditampilkan.

\section{HASIL DAN PEMBAHASAN}

Mendasarkan pada pengamatan visual dan hasil yang diperoleh, lokasi Klaten cenderung memberikan kondisi yang optimum dan lokasi Sleman memberikan kondisi yang kurang optimum. Terjadinya kekeringan di Sleman, kemudian banyak gulma di sekitar pertanaman padi, serangan penyakit sejak awal masa generatif dan hama selama pascapanen menyebabkan pertumbuhan padi tidak optimum dan hasil tidak maksimal. Kondisi sebaliknya terjadi di Klaten sehingga pertumbuhan baik sehingga hasil yang diperoleh tinggi. Keragaan dari komponen hasil yang diamati dari masing-masing genotipe di dua lokasi ditampilkan pada Tabel 1.

Secara umum tanaman padi yang ditanam di lokasi Sleman memiliki jumlah anakan total lebih banyak, tinggi tanaman lebih rendah, daun bendera lebih pendek, umur berbunga dan umur panen lebih panjang, bobot 100 butir biji lebih rendah, jumlah malai per rumpun lebih banyak, malai lebih panjang, tingkat kehampaan malai lebih tinggi, jumlah biji per malai lebih sedikit, kerapatan malai lebih jarang, kemudian hasil per hektar lebih kecil. Keragaan tersebut diperkirakan merupakan tanggapan padi ketika ditanam di lingkungan yang kurang optimum. Padi akan tumbuh dengan lebih kecil, lebih pendek, namun akan menambah jumlah anakan, dengan masing-masing anakan lebih kecil, berisi lebih sedikit biji, lebih ringan, dan banyak yang hampa 
sehingga hasil lebih sedikit. Pembungaan akan tertunda sehingga umur panen lebih lama. Hal sebaliknya dialami padi yang tumbuh di Klaten, meski memiliki sedikit anakan, namun ukuran malai besar, isinya lebih banyak, berbunga lebih cepat, biji memiliki bobot yang lebih besar, dan hasil lebih tinggi, bahkan melebihi produktivitas nasional.

Perbedaan yang mencolok di kedua lokasi menyebabkan keragaman akibat pengaruh lokasi tumbuh menjadi sangat besar. Genotipe juga memberikan pengaruh pada keragaman semua komponen hasil yang diamati, namun pendugaan komponen varian dan kovarian genetik akan dilakukan melalui analisis per lokasi, bukan analisis gabungan sebagaimana digunakan untuk menunjukkan keragaman. Hal ini disebabkan tingginya pengaruh lokasi dan interaksi genotipe $\mathrm{x}$ lokasi menutupi pengaruh genotipe sehingga keragaman genotipe tidak bisa diduga dengan ANOVA gabungan. 
M. Mujadid Faiqon et al., / Vegetalika. 2017. 6(2): 14-24

Tabel 1. Keragaan komponen hasil dan hasil padi di Sleman dan Klaten

\begin{tabular}{|c|c|c|c|c|c|c|c|c|c|c|c|c|}
\hline \multirow[t]{2}{*}{ Genotipe } & \multicolumn{2}{|c|}{ Jumlah anakan total } & \multicolumn{2}{|c|}{$\begin{array}{l}\text { Tinggi tanaman } \\
(\mathrm{cm})\end{array}$} & \multicolumn{2}{|c|}{$\begin{array}{l}\text { Panjang daun bendera } \\
(\mathrm{cm})\end{array}$} & \multicolumn{2}{|c|}{$\begin{array}{c}\text { Umur berbunga } \\
\text { (hari setelah semai) }\end{array}$} & \multicolumn{2}{|c|}{$\begin{array}{c}\text { Umur panen } \\
\text { (hari setelah semai) }\end{array}$} & \multicolumn{2}{|c|}{ Bobot 100 butir biji } \\
\hline & Klaten & Sleman & Klaten & Sleman & Klaten & Sleman & Klaten & Sleman & Klaten & Sleman & Klaten & Sleman \\
\hline IR64 & 17,89 hij & $31,73 \mathrm{a}$ & $82,71 \mathrm{gh}$ & $62,66 j$ & $18,96 \mathrm{ghi}$ & $19,84 \mathrm{fg}$ & $90,33 \mathrm{~g}$ & $92,00 \mathrm{fg}$ & $115,33 \mathrm{j}$ & $123,00 \mathrm{gh}$ & $2,72 a b$ & $2,23 \mathrm{hi}$ \\
\hline Memberamo & $19,27 \mathrm{f}-\mathrm{i}$ & $25,73 b$ & $96,13 \mathrm{~cd}$ & $78,87 \mathrm{hi}$ & 22,31 b-e & $18,90 \mathrm{ghi}$ & $94,00 \mathrm{f}$ & $102,00 \mathrm{f}$ & $120,67 \mathrm{hi}$ & $131,00 \mathrm{~cd}$ & $2,68 \mathrm{bc}$ & 2,42 ef \\
\hline Sidenuk Pak & $14,26 \mathrm{k}$ & 22,47 cde & $105,77 \mathrm{~b}$ & 79,49 hi & $22,96 \mathrm{bc}$ & $17,25 \mathrm{i}$ & $93,33 \mathrm{f}$ & $103,67 \mathrm{~cd}$ & $124,67 \mathrm{fg}$ & $133,33 \mathrm{bc}$ & $2,81 \mathrm{a}$ & $2,29 \mathrm{gh}$ \\
\hline Tiwi-I UGM & $19,20 \mathrm{~g}-\mathrm{j}$ & $24,80 \mathrm{bc}$ & $102,45 \mathrm{bc}$ & $72,25 \mathrm{i}$ & $26,88 \mathrm{a}$ & $17,40 \mathrm{hi}$ & $98,67 \mathrm{e}$ & $107,00 a b$ & $130,00 \mathrm{de}$ & $140,00 \mathrm{a}$ & 2,39 efg & 2,23 hi \\
\hline 1271 & $16,93 \mathrm{i}-\mathrm{k}$ & $20,93 \mathrm{~d}-\mathrm{h}$ & 95,92 cde & $87,58 \mathrm{fg}$ & $20,53 d-g$ & $28,27 \mathrm{a}$ & $94,00 \mathrm{f}$ & $97,00 \mathrm{e}$ & 119,67 i & $\begin{array}{l}132,00 \\
\text { bcd }\end{array}$ & $2,68 \mathrm{bc}$ & $2,57 \mathrm{~cd}$ \\
\hline UGM 8 & 17,13 i-k & $22,40 c-f$ & $113,71 \mathrm{a}$ & $85,87 \mathrm{fgh}$ & $26,97 \mathrm{a}$ & 20,21 efg & $103,3 \mathrm{~cd}$ & $101,67 d$ & $133,33 \mathrm{bc}$ & $141,00 \mathrm{a}$ & 2,44 ef & $2,03 \mathrm{j}$ \\
\hline UGM 11 & 19,40 e-i & $22,27 \mathrm{c}-\mathrm{g}$ & 88,37 efg & $78,51 \mathrm{hi}$ & $21,32 c-f$ & $20,94 c-9$ & $97,67 \mathrm{e}$ & $103,33 \mathrm{~cd}$ & 127,33 ef & $141,33 \mathrm{a}$ & $2,46 \mathrm{de}$ & $2,03 j$ \\
\hline UGM 28 & 16,07 jk & $21,07 d-h$ & $105,39 \mathrm{~b}$ & 92,71 def & $24,04 \mathrm{~b}$ & $20,95 c-9$ & $97,00 \mathrm{e}$ & $106,00 \mathrm{bc}$ & $129,67 \mathrm{de}$ & $134,67 \mathrm{~b}$ & $2,94 \mathrm{de}$ & $2,15 \mathrm{ij}$ \\
\hline UGM 30 & $17,20 \mathrm{ijk}$ & 22,87 b-d & $102,35 \mathrm{bc}$ & $78,49 \mathrm{hi}$ & $22,65 \mathrm{bcd}$ & $19,52 \mathrm{fgh}$ & $102,33 \mathrm{~d}$ & $109,00 \mathrm{a}$ & $134,33 \mathrm{~b}$ & $141,00 \mathrm{a}$ & $2,70 a b$ & $2,33 \mathrm{fgh}$ \\
\hline Rerata & 17,48 & 23,81 & 99,20 & 79,6 & 22,96 & 20,36 & 96,74 & 102,41 & 126,11 & 135,36 & 2,60 & 2,25 \\
\hline CV (\%) & \multicolumn{2}{|c|}{0,08} & \multicolumn{2}{|c|}{0,05} & \multicolumn{2}{|c|}{0,05} & \multicolumn{2}{|c|}{0,02} & \multicolumn{2}{|c|}{0,02} & \multicolumn{2}{|c|}{0,03} \\
\hline \multirow[t]{2}{*}{ Genotipe } & \multicolumn{2}{|c|}{ Jumlah malai } & \multicolumn{2}{|c|}{ Panjang malai $(\mathrm{cm})$} & \multicolumn{2}{|c|}{$\begin{array}{c}\text { Persen malai hampa } \\
\text { (persen/malai) }\end{array}$} & \multicolumn{2}{|c|}{$\begin{array}{c}\text { Jumlah biji per malai } \\
\text { (biji/malai) }\end{array}$} & \multicolumn{2}{|c|}{$\begin{array}{c}\text { Kerapatan malai } \\
\text { (biji/cm) }\end{array}$} & \multicolumn{2}{|c|}{$\begin{array}{l}\text { Hasil per hektar } \\
\text { (ton/ha) }\end{array}$} \\
\hline & Klaten & Sleman & Klaten & Sleman & Klaten & Sleman & Klaten & Sleman & Klaten & Sleman & Klaten & Sleman \\
\hline IR64 & $14,07 \mathrm{fg}$ & $27,73 \mathrm{~b}$ & $19,94 \mathrm{fgh}$ & $15,70 \mathrm{i}$ & $0,07 \mathrm{f}$ & 0,08 ef & $94,67 \mathrm{e}$ & $57,83 \mathrm{f}$ & $4,75 \mathrm{~g}$ & $3,68 \mathrm{~h}$ & $6,52 \mathrm{bc}$ & $2,43 \mathrm{fgh}$ \\
\hline Memberamo & $14,33 \mathrm{fg}$ & $21,67 \mathrm{bc}$ & $22,91 \mathrm{~b}$ & 20,32 efg & 0,11 def & $0,18 a b c$ & $143,29 d$ & 100,82 e & $6,25 \mathrm{f}$ & $4,96 \mathrm{~g}$ & $8,32 \mathrm{a}$ & 3,97 ef \\
\hline Sidenuk Pak & $8,07 \mathrm{gh}$ & $18,87 d$ & $24,67 \mathrm{a}$ & 19,02 hij & 0,13 cde & 0,11 def & $194,53 a b c$ & $99,13 \mathrm{e}$ & $7,89 \mathrm{~cd}$ & $5,19 \mathrm{~g}$ & 4,40 de & 3,68 efg \\
\hline Tiwi-I UGM & $12,67 \mathrm{j}$ & $21,80 \mathrm{~b}$ & 21,14 def & $18,22 \mathrm{jk}$ & $0,08 \mathrm{f}$ & $0,22 \mathrm{a}$ & $205,91 a b$ & $92,80 \mathrm{e}$ & $9,74 a$ & $5,08 \mathrm{~g}$ & $7,68 \mathrm{ab}$ & $2,35 \mathrm{gh}$ \\
\hline 1271 & $12,40 \mathrm{gh}$ & $14,07 \mathrm{fg}$ & $22,69 \mathrm{bc}$ & 21,48 cde & 0,11 def & $0,20 \mathrm{abc}$ & $145,27 d$ & $141,73 \mathrm{~d}$ & $6,39 \mathrm{f}$ & 6,58 ef & $6,13 \mathrm{bc}$ & $2,62 \mathrm{fgh}$ \\
\hline UGM 8 & $11,27 \mathrm{hi}$ & 16,53 def & 20,83 def & $17,14 \mathrm{k}$ & 0,09 ef & $0,14 \mathrm{~cd}$ & $188,87 \mathrm{bc}$ & $139,13 \mathrm{~d}$ & $9,06 \mathrm{ab}$ & $8,10 \mathrm{~cd}$ & $8,18 \mathrm{a}$ & $2,00 \mathrm{~h}$ \\
\hline UGM 11 & 14,67 efg & $17,27 \mathrm{de}$ & $23,12 b$ & $17,07 \mathrm{k}$ & 0,08 ef & $0,17 \mathrm{bbc}$ & $150,13 d$ & $129,78 \mathrm{~d}$ & $6,49 \mathrm{f}$ & $7,58 d$ & $7,20 \mathrm{abc}$ & $1,95 \mathrm{~h}$ \\
\hline UGM 28 & $9,00 \mathrm{ij}$ & $17,60 \mathrm{~d}$ & $21,90 \mathrm{bcd}$ & $18,60 \mathrm{ij}$ & 0,08 ef & 0,12 def & $215,62 \mathrm{a}$ & $172,98 \mathrm{c}$ & $9,84 \mathrm{a}$ & $9,30 a b$ & $6,02 \mathrm{c}$ & 3,82 efg \\
\hline UGM 30 & $9,47 \mathrm{ij}$ & $19,11 \mathrm{~cd}$ & $22,94 \mathrm{~b}$ & 19,53 ghi & 0,09 ef & $0,19 a b$ & $197,56 a b$ & $144,00 \mathrm{~d}$ & $8,6 \mathrm{bc}$ & 7,37 de & $5,85 \mathrm{~cd}$ & 3,07 e-h \\
\hline Rerata & 11,77 & 19,4 & 22,24 & 18,56 & 0,09 & 0,16 & 170,65 & 119,8 & 7,67 & 6,43 & 6,7 & 2,88 \\
\hline CV (\%) & \multicolumn{2}{|c|}{0,09} & \multicolumn{2}{|c|}{0,03} & \multicolumn{2}{|c|}{0,23} & \multicolumn{2}{|c|}{0,08} & \multicolumn{2}{|c|}{0,07} & \multicolumn{2}{|c|}{0,17} \\
\hline
\end{tabular}

Keterangan: Semua interaksi nyata, huruf yang sama di belakang kolom sifat yang sama menunjukkan tidak ada beda nyata antar genotipe. 
M. Mujadid Faiqon et al., / Vegetalika. 2017. 6(2): 14-24

Tabel 2. Rerata, rentang nilai, dan heritabilitas komponen hasil dan hasil.

\begin{tabular}{|c|c|c|c|c|c|c|}
\hline \multirow{2}{*}{ Karakter } & \multicolumn{2}{|c|}{ Rerata } & \multicolumn{2}{|c|}{ Rentang } & \multicolumn{2}{|c|}{ Heritabilitas } \\
\hline & Sleman & Klaten & Sleman & Klaten & Sleman & Klaten \\
\hline JA (buah) & 23,81 & 17,48 & $17,60-32,60$ & $11,80-21,8$ & 0,77 & 0,25 \\
\hline TT (cm) & 79,60 & 99,20 & $60,26-0,94$ & $78,6-116,42$ & 0,84 & 0,76 \\
\hline PDB (cm) & 20,36 & 22,96 & $16,28-28,65$ & $17,15-28,27$ & 0,87 & 0,76 \\
\hline UB (hari) & 102,41 & 96,74 & $91,00-110,00$ & $90-105$ & 0,88 & 0,92 \\
\hline UP (hari) & 135,26 & 126,11 & $122,00-143,00$ & $115-136$ & 0,93 & 0,89 \\
\hline B100 (gram) & 2,25 & 2,60 & $2,00-2,61$ & $2,33-2,87$ & 0,87 & 0,74 \\
\hline JM (buah) & 19,40 & 11,77 & $13,00-29,40$ & $5,8-16,0$ & 0,82 & 0,77 \\
\hline PM (cm) & 18,56 & 22,24 & $15,44-22,08$ & $19,76-25,61$ & 0,80 & 0,84 \\
\hline PH (persen/malai) & 0,16 & 0,09 & $0,08-0,30$ & $0,06-0,15$ & 0,53 & 0,44 \\
\hline JB (buah/malai) & 119,80 & 170,65 & $57,52-181,27$ & $90,73-233,27$ & 0,83 & 0,93 \\
\hline KM (buah/cm) & 6,43 & 7,67 & $3,62-9,65$ & $4,59-10,34$ & 0,90 & 0,96 \\
\hline HPH (ton/ha) & 2,88 & 6,70 & $1,00-2,88$ & $3,09-9,03$ & 0,42 & 0,55 \\
\hline
\end{tabular}

Keterangan: JA = jumlah anakan total; TT = tinggi tanaman; PDB = panjang daun bendera; UB = umur berbunga; UP = umur panen; $\mathrm{B} 100 \mathrm{~B}=$ bobot 100 butir biji; JM = jumlah malai; $\mathrm{PM}=$ panjang malai; $\mathrm{PH}=$ persentase malai hampa; $\mathrm{JB}=$ jumlah biji per malai; $\mathrm{KM}=\mathrm{kerapatan}$ malai; $\mathrm{HPH}=$ hasil per hektar. 
Di antara semua parameter genetik, heritabilitas merupakan yang paling penting karena menggambarkan besar pengaruh genotipe dalam membentuk keragaman. Suatu heritabilitas tergolong besar bila bernilai lebih dari 0,5, sedang pada rentang 0,2 hingga 0,5 dan rendah bila di bawah 0,2 (Mangoendidjojo, 2003). Hasil pendugaan heritabilitas pada tabel 2 menunjukkan bahwa semua komponen hasil memiliki heritabilitas yang tergolong tinggi dan lebih tinggi dibandingkan hasil per hektar pada masing-masing lokasi kecuali untuk sifat persentase malai hampa dan jumlah anakan di lokasi Klaten. Jumlah anakan genotipe padi berdaya hasil tinggi pada lingkungan yang optimum cenderung berada pada rentang yang berdekatan sehingga keragaman genetiknya rendah. Persentase malai hampa lebih banyak disebabkan oleh kondisi lingkungan. Heritabilitas yang relatif lebih rendah, meskipun tergolog sedang, dan tinggi 0,44 di Klaten dan 0,53 di Sleman membuktikan hal tersebut. Heritabilitas semua sifat di lokasi Klaten diperkirakan mewakili heritabilitas komponen hasil di lokasi optimum dan di lokasi Sleman mewakili heritabilitas komponen hasil di lokasi yang tidak optimum. Nilai heritabilitas yang tinggi merupakan sesuatu yang wajar dan sudah banyak dibuktikan oleh banyak penelitian lain (El Malky et al., 2003 Ali et al., 2009; Akinwale et al., 2011; ; Susanti et al., 2011; Nilajaya and Kumar, 2015). Semua sifat kecuali jumlah anakan dan persentase malai hampa di lokasi Klaten dengan heritabilitas yang tinggi merupakan sifat yang telah memenuhi satu syarat untuk dapat digunakan sebagai sifat yang diseleksi dalam seleksi tidak langsung peningkatan daya hasil.

Tabel 3. Analisis lintas komponen hasil terhadap hasil per hektar (HPH) di lokasi Klaten

\begin{tabular}{ccccccccccc}
\hline & $T T$ & $P D B$ & $U B$ & $U P$ & $B 100 B$ & $J M$ & $P H$ & $J B$ & $K M$ & $T O T A L$ \\
\hline$T T$ & $-1,08$ & 1,55 & 0,92 & $-0,96$ & $-0,07$ & $-0,13$ & $-0,01$ & 0,04 & $-0,32$ & $-0,06$ \\
$P D B$ & $-0,95$ & 1,76 & 1,03 & $-0,99$ & $-0,17$ & $-0,06$ & 0,00 & 0,04 & $-0,33$ & 0,33 \\
UB & $-0,71$ & 1,30 & 1,40 & $-1,23$ & $-0,14$ & $-0,05$ & 0,01 & 0,03 & $-0,27$ & 0,34 \\
UP & $-0,82$ & 1,37 & 1,35 & $-1,27$ & $-0,14$ & $-0,08$ & 0,01 & 0,04 & $-0,33$ & 0,13 \\
$B 100 B$ & 0,31 & $-1,29$ & $-0,87$ & 0,79 & 0,23 & $-0,04$ & $-0,02$ & $-0,02$ & 0,20 & $-0,70$ \\
$J M$ & 0,86 & $-0,65$ & $-0,43$ & 0,65 & $-0,05$ & 0,16 & 0,01 & $-0,04$ & 0,25 & 0,76 \\
$P H$ & $-0,32$ & $-0,21$ & $-0,57$ & 0,40 & 0,18 & $-0,05$ & $-0,03$ & 0,01 & 0,04 & $-0,57$ \\
$J B$ & $-0,96$ & 1,44 & 0,94 & $-1,10$ & $-0,09$ & $-0,12$ & $-0,01$ & 0,05 & $-0,36$ & $-0,21$ \\
$K M$ & $-0,95$ & 1,59 & 1,01 & $-1,12$ & $-0,13$ & $-0,11$ & 0,00 & 0,05 & $-0,37$ & $-0,02$ \\
\hline \multicolumn{10}{c}{} \\
\hline
\end{tabular}

Keterangan: Kolom diagonal merupakan penduga koefisien lintas atau pengaruh langsung sifat pada kolom paling kiri terhadap hasil per hektar $(\mathrm{HPH})$. Elemen dalam satu baris yang sama kecali elemen diagonal merupakan penduga pengaruh tidak langsung siat pada kolom paling kiri terhadap hasil per hektar $(\mathrm{HPH})$ melalui sifat pada kolom paling atas. Korelasi genetik sifat pada kolom paling kiri terhadap hasil per hektar atau pengaruh total ditampilkan pada kolom paling kanan.

Parameter kedua yang akan diduga adalah koefisien korelasi genetik. Di lokasi Klaten, komponen hasil yang berkorelasi genetik terhadap hasil per hektar adalah 
panjang daun bendera $(0,33)$, umur berbunga $(0,34)$, dan jumlah malai $(0,76)$. Ketiganya adalah sifat yang berkorelasi di wilayah penanaman yang optimum. Meskipun jumlah malai memiliki pengaruh total paling tinggi namun pengaruh langsungnya cenderung rendah sedangkan sifat lain yang berpengaruh terhadap korelasi genetik jumlah malai terhadap hasil per hektar adalah tinggi tanaman dan umur panen. Keduanya memang memberikan jalur pengaruh tidak langsung yang tinggi untuk jumlah malai, namun terhadap sifat lain lebih banyak memberikan pengaruh negatif, misalnya pada panjang daun bendera dan umur berbunga. Kedua sifat tersebut merupakan sifat dengan pengaruh langsung yang tinggi, yaitu 1,76 dan 1,40 dan akan lebih tinggi bila pengaruh tidak langsung malali tinggi tanaman dan umur panen diturunkan. Oleh karena itu jika seleksi dilakukan bersama maka diperlukan pembatasan terhadap tinggi tanaman dan umur panen sehingga tidak berdampak menurunkan korelasi jumlah malai namun meningkatkan korelasi panjang daun bendera dan umur berbunga. Sifat yang tidak diikutsertakan dalam model adalah sifat dengan nilai penduga koefisien korelasi genetik tidak terdefinisi karena lebih besar dari 1 atau kurang dari -1 yang disebabkan oleh ketidakmampuan model untuk menjelaskan hubungan $P=G+E$ pada sifat tersebut.

Tabel 4. Analisis lintas komponen hasil terhadap hasil per hektar (HPH) di lokasi Sleman

\begin{tabular}{|c|c|c|c|c|c|c|c|c|c|c|c|}
\hline & $J A$ & $T T$ & $P D B$ & $U B$ & $U P$ & $B 100 B$ & $J M$ & $P M$ & $P H$ & $J B$ & Total \\
\hline$J A$ & $-1,56$ & 0,48 & 1,00 & 1,38 & $-0,75$ & 0,03 & 1,02 & 0,49 & 0,24 & $-2,47$ & $-0,15$ \\
\hline$T T$ & 1,44 & $-0,52$ & $-1,26$ & $-0,91$ & 0,44 & 0,03 & $-0,95$ & $-0,45$ & $-0,08$ & 2,55 & 0,29 \\
\hline$P D B$ & 0,53 & $-0,22$ & $-2,95$ & 1,01 & $-0,13$ & 1,4 & $-0,6$ & $-0,38$ & $-0,13$ & 1,18 & $-0,31$ \\
\hline$U B$ & 0,92 & $-0,2$ & 1,27 & $-2,34$ & 0,84 & $-0,69$ & $-0,34$ & $-0,24$ & $-0,33$ & 1,46 & 0,36 \\
\hline$U P$ & 1,11 & $-0,21$ & 0,37 & $-1,87$ & 1,05 & $-1,42$ & $-0,59$ & $-0,05$ & $-0,4$ & 1,65 & $-0,37$ \\
\hline$B 100 B$ & $-0,01$ & 0 & $-1,32$ & 0,52 & $-0,48$ & 3,13 & $-0,06$ & $-0,73$ & $-0,26$ & $-0,34$ & 0,44 \\
\hline$J M$ & $-1,56$ & 0,48 & 1,74 & 0,78 & $-0,62$ & $-0,18$ & 1,02 & 0,49 & 0,23 & $-2,38$ & $-0,01$ \\
\hline$P M$ & 0,88 & $-0,27$ & $-1,29$ & $-0,64$ & 0,06 & 2,63 & $-0,57$ & $-0,87$ & $-0,37$ & 1,01 & 0,55 \\
\hline $\mathrm{PH}$ & 0,62 & $-0,07$ & $-0,65$ & $-1,28$ & 0,7 & 1,37 & $-0,39$ & $-0,54$ & $-0,61$ & 0,72 & $-0,12$ \\
\hline$J B$ & 1,39 & $-0,47$ & $-1,25$ & $-1,23$ & 0,63 & $-0,39$ & $-0,87$ & $-0,32$ & $-0,16$ & 2,77 & 0,10 \\
\hline & & & & & & & & & \multicolumn{2}{|c|}{ Total } & 0,96 \\
\hline & & & & & & & & & \multicolumn{2}{|c|}{ Residu } & 0,04 \\
\hline
\end{tabular}

Keterangan: Kolom diagonal merupakan penduga koefisien lintas atau pengaruh langsung sifat pada kolom paling kiri terhadap hasil per hektar $(\mathrm{HPH})$. Elemen dalam satu baris yang sama kecali elemen diagonal merupakan penduga pengaruh tidak langsung siat pada kolom paling kiri terhadap hasil per hektar $(\mathrm{HPH})$ melalui sifat pada kolom paling atas. Korelasi genetik sifat pada kolom paling kiri terhadap hasil per hektar atau pengaruh total ditampilkan pada kolom paling kanan.

Sifat yang berkorelasi genetik di wilayah Sleman adalah tinggi tanaman $(0,29)$, umur berbunga $(0,36)$, bobot 100 butir biji $(0,44)$, dan panjang malai $(0,55)$. Sifat-sifat tersebut diperkirakan merupakan sifat yang berkorelasi genetik terhadap hasil per hektar pada padi di wilayah yang kurang optimum. Bobot 100 biji menjadi satu-satunya sifat di antara keempat sifat tersebut yang memiliki pengaruh langsung tinggi dan positif, yaitu 3,13 sedangkan untuk sifat lain pengaruh langsungnya negatif. Oleh karena itu 
bobot 100 biji dapat dipilih secara langsung untuk peningkatan hasil per hektar karena korelasinya menunjukkan hubungan yang sebenarnya antar kedua sifat tersebut di lokasi Sleman. Selain bobot 100 butir biji, jumlah malai dan jumlah biji per malai juga dapat digunakan untuk seleksi karena pengaruh langsungnya yang tinggi, yaitu 1,02 dan 2,77 , namun kedua sifat dapat dikatakan saling menurunkan satu sama lain sehingga harus dipilih salah satu sifat saja. Jumlah biji per malai diperkirakan menjadi sifat yang lebih penting dibandingkan jumlah malai karena menjadi jalur pengaruh tidak langsung positif tinggi tanaman, umur berbunga, dan panjang malai sehingga korelasi genetik ketiganya terhadap hasil per hektar tinggi serta memiliki pengaruh langsung yang lebih tinggi dibandingkan jumlah malai. Pembatasan dilakukan terhadap panjang daun bendera, jumlah malai, dan umur berbunga bila seleksi dilakukan untuk banyak sifat sekaligus sehingga tidak menyebabkan pengaruh tidak langsung negatif melalui sifat-sifat lain.

Tabel 5. Heritabilitas, korelasi genetik ( $\mathrm{rg}$ ) komponen hasil terhadap hasil per hektar $(\mathrm{HPH})$, rasio kemajuan seleksi tidak langsung dan seleksi langsungnya (CRA/RA) dan koheritabilitas komponen hasil terhadap hasil per hektar (HPH).

\begin{tabular}{|c|c|c|c|c|c|c|c|c|}
\hline \multirow{2}{*}{ Karakter } & \multicolumn{2}{|c|}{ Heritabilitas } & \multicolumn{2}{|c|}{$r_{g}$} & \multicolumn{2}{|c|}{ Koheritabilitas } & \multicolumn{2}{|c|}{$\mathrm{CR}_{\mathrm{A}} / \mathrm{R}_{\mathrm{A}}$} \\
\hline & Sleman & Klaten & Sleman & Klaten & Sleman & Klaten & Sleman & Klaten \\
\hline JA & 0,77 & 0,25 & $-0,15$ & - & $-0,08$ & - & $-0,20$ & - \\
\hline TT & 0,84 & 0,76 & 0,29 & $-0,06$ & 0,17 & $-0,04$ & 0,42 & $-0,08$ \\
\hline PDB & 0,87 & 0,76 & $-0,31$ & 0,33 & $-0,18$ & 0,21 & $-0,44$ & 0,38 \\
\hline UB & 0,88 & 0,92 & 0,36 & 0,34 & 0,22 & 0,24 & 0,52 & 0,44 \\
\hline UP & 0,93 & 0,89 & $-0,37$ & 0,13 & $-0,23$ & 0,09 & $-0,55$ & 0,16 \\
\hline B100B & 0,87 & 0,74 & 0,44 & $-0,70$ & 0,27 & $-0,45$ & 0,63 & $-0,82$ \\
\hline JM & 0,82 & 0,77 & $-0,01$ & 0,76 & 0,00 & 0,49 & $-0,01$ & 0,90 \\
\hline PM & 0,80 & 0,84 & 0,55 & $-0,59$ & 0,32 & $-0,40$ & 0,76 & $-0,73$ \\
\hline $\mathrm{PH}$ & 0,53 & 0,44 & $-0,12$ & $-0,57$ & $-0,06$ & $-0,28$ & $-0,14$ & $-0,51$ \\
\hline JB & 0,83 & 0,93 & 0,10 & $-0,21$ & 0,06 & $-0,15$ & 0,14 & $-0,28$ \\
\hline $\mathrm{KM}$ & 0,90 & 0,96 & $-0,07$ & $-0,02$ & $-0,04$ & $-0,02$ & $-0,10$ & $-0,03$ \\
\hline $\mathrm{HPH}$ & 0,42 & 0,55 & & & & & & \\
\hline
\end{tabular}

Kemajuan seleksi tidak langsung diduga dengan CRA yang nilainya bergantung pada korelasi genetik dan koheritabilitas sifat yang diseleksi terhadap hasil sedangkan kemajuan seleksi langsung diduga dengan RA yang nilainya bergantung pada heritabilitas hasil. Nilai tersebut merupakan nilai harapan atau penduga karena seleksi tidak benar-benar dilakukan. Rasio nilai harapan CRA/RA akan menghasilkan nilai yang lebih dari 1 bila kemajuan seleksi tidak langsung lebih tinggi dibandingkan seleksi langsungnya. Hasil penelitian ini menunjukkan bahwa tidak ada sifat yang dapat meningkatkan kemajuan genetik hasil per hektar melalui seleksi tidak langsung. Korelasi genetik yang tidak cukup tinggi antara komponen hasil terhadap hasil dan heritabilitas hasil yang sudah cukup tinggi, 0,42 dan 0,55 menyebabkan koheritbilitas komponen hasil rendah, di bawah 0,5. Koheritabilitas yang rendah menyebabkan 
kemajuan genetik seleksi tidak langsung menjadi rendah dan tidak mampu mengungguli kemajuan seleksi langsung.

Beberapa komponen hasil memang berkorelasi genetik terhadap hasil, sebagaimana dibahas dalam analisis sebelumnya, namun hal tersebut tidak cukup untuk menjadikannya sebagai sifat yang dapat meningkatkan kemajuan genetik hasil. Pleitropy sebagai dasar yang menjadi sebab munculnya korelasi genetik memang ada namun tidak cukup besar atau tidak terjadi pada banyak gen sehingga pengaruhnya pun kecil. Heritabilitas komponen hasil yang tinggi menunjukkan bahwa keragaman pada komponen hasil akan terwariskan, namun heritabilitas hasil juga sudah cukup tinggi sehingga seleksi langsung bisa dilakukan dengan cukup efektif.

\section{KESIMPULAN}

Tidak terdapat komponen hasil yang diamati yang mampu menghasilkan kemajuan genetik untuk hasil per hektar lebih tinggi melalui seleksi tidak langsung berdasarkan rasio nilai harapan CRA/RA-nya sehingga seleksi langsung lebih efektif untuk peningkatan daya hasil.

\section{DAFTAR PUSTAKA}

Akinwale, M.G., G. Greorio, F. Nwilene, B.O. Akinyele, S.A. Ogunbayo and A.C. Odiyl. 2011. Heritability and correlation coefficient analysis for yield and its components in rice (Oryza sativa L.). African Journal of Plant Science. 5: 207212.

Ali, S.S., S.J.H. Jafri, T.Z. Khan, A. Mahmood, and M.A. Butt. 2000. Heritability of yield and yield components of rice. Pakistan Journal of Agricultural Resource. 16:8991.

Anonim. 2014. Buletin konsumsi pangan. Pusat Data dan Sistem Informasi Pertanian. 5 : 2014.

Anonim. 2016. Sistem informasi pangan strategis. <https://aplikasi2.pertanian.go.id/sipastra/>. Diakses tanggal 29 Maret 2016.

El-Malky,M., M. El-Habashy, and A.F. Abdelkhalik. 2008. Rice germplasm evaluation for agronomic traits and their influence on stem borer (Chilo agamemnon bles.) resistance. Journal of Agriculurture Ressistance. 46 : 206-212.

Falconer, D.S. and T.F.C. Mackay. 1996. Introduction to quantitative genetics. Fourth Edition. Longman, Malaysia.

Mangoendidjojo, 2003. Dasar-dasar pemuliaan tanaman. Kanisius, Yogyakarta.

Nilanjaya and C. Kumar. 2015. Inheritability, character association and cause effect study among yield attributes in aerobic rice (Oryza sativa L.). The Ecoscan. 9: 591-596. 
M. Mujadid Faiqon et al., / Vegetalika. 2017. 6(2): 14-24

Peng, S., K.G. Cassman, S.S. Virmani, J. Sheehy and G.S. Khush. 1999. Yield potential trends of tropical rice since the release of IR8 and the challenge of increasing rice yield potential. Crop Science. 39:1552-1559.

Poehlman, J.M. 1987. Quantitative inheritance in plant breeding. In: Poehlman, J.M. Breeding field crops. Springer, Netherlands.

Roy, D. 2000. Plant breeding, analysis and exploitation of variation. Narosa Publishing House, New Delhi.

Susanti, D., Suwarto, dan T.A.D. Haryanto. 2011. Evaluasi karakter penduga hasil pada populasi genotip F3 persilangan Silungonggo x Milky Rice berdasarkan sidik lintas. Agronomika. 11: 136-143. 